\title{
NUMERICAL ANALYSIS OF DIAPHRAGM WALL MODEL EXECUTED IN POZNAŃ CLAY FORMATION APPLYING SELECTED FEM CODES
}

\author{
M. SUPERCZYŃSKA ${ }^{1}$, K. JÓZEFIAK ${ }^{2}$, A. ZBICIAK ${ }^{3}$
}

\begin{abstract}
The paper presents results of numerical calculations of a diaphragm wall model executed in Poznań clay formation. Two selected FEM codes were applied, Plaxis and Abaqus. Geological description of Poznań clay formation in Poland as well as geotechnical conditions on construction site in Warsaw city area were presented. The constitutive models of clay implemented both in Plaxis and Abaqus were discussed. The parameters of the Poznań clay constitutive models were assumed based on authors' experimental tests. The results of numerical analysis were compared taking into account the measured values of horizontal displacements.
\end{abstract}

Keywords: Poznań clay formation, Constitutive modelling, FEM, Computational geotechnics, Diaphragm wall

\section{INTRODUCTION}

In dense urban areas the construction of foundation can be extremely difficult. The difficulties can be caused not only by close vicinity of other buildings and infrastructure but also by special soil conditions (e.g. expansive or collapsible soils) [10]. Foundation engineers and geologists should be able to identify difficult soil conditions when they are encountered in the field [20,21].

\footnotetext{
${ }^{1}$ PhD., Warsaw University of Technology, Institute of Roads and Bridges, 16 Armii Ludowej Ave, 00-637 Warsaw, Poland, e-mail: m.superczynska@il.pw.edu.pl

2 MSc., Eng., Warsaw University of Technology, Institute of Roads and Bridges, 16 Armii Ludowej Ave, 00-637 Warsaw, Poland, e-mail: k.jozefiak@il.pw.edu.pl

${ }^{3}$ Prof., DSc., PhD., Eng., Warsaw University of Technology, Institute of Roads and Bridges, 16 Armii Ludowej Ave, 00637 Warsaw, Poland, e-mail: a.zbiciak@il.pw.edu.pl
} 
The diaphragm wall we analyse in this paper was executed in Warsaw city area having difficult subsoil conditions with complicated geological past. This is the Poznan clay formation appearing very often in central Poland as a subsoil of high buildings and underground structures. Special properties of the Poznan clay, its expansiveness and variation of elastic moduli being sometimes several times higher than those presented in codes and literature, make both design and construction processes very difficult.

The objective of our paper is to present selected results of numerical calculations of diaphragm wall model. The analysis was performed with the use of two Finite Element Method (FEM) codes, Plaxis and Abaqus. Both codes contain appropriate elastic-plastic models of soils suited for clay modelling but the application of these models needs good knowledge of mechanics and geotechnics [4, 7, 9]. Moreover, there are certain differences in constitutive formulation of elastic-plastic models in Plaxis and Abaqus. Our objective was also to point out these differences and to present selected elements of constitutive theory being not explained in detail in manuals of both codes. In some cases, special techniques of FEM modelling implemented within the software were used (e.g. user defined subroutines in Abaqus).

The results of computer calculations will be compared with measured values of horizontal displacements of the diaphragm wall. Moreover, the analysis of effective stress components in soil layers will be also carried out.

\section{PozNAŃ Clay FORMATION IN WARSAW}

In the central Poland the Poznań Formation has developed as a clay which often appears as a subsoil for high buildings and underground structures. The sedimentation of clays began 13 million years ago, and it lasted 9 million years. The layer of clays reached about 150 meters height. Special influence on original structure of soil had seismic, river erosion, glacitectonic and weathering processes [1]. It led to the formation of folds, displacements, tectonic mirrors and lenses with water under high pressure in the mass of clays. Clays lies under Quaternary deposits layer in Warsaw and its original thickness was 100-140 meters. There are numerous depressions and elevation on NNWSSE direction (as a result of glacitectonics and erosion processes). Now, the average thickness of deposits is 50 meters, and the denivelation of clays layer reaches $100 \mathrm{~m}$. Major dislocations are connected with Warta's glaciation [18]. A typical geological section is shown in Fig. 1. 


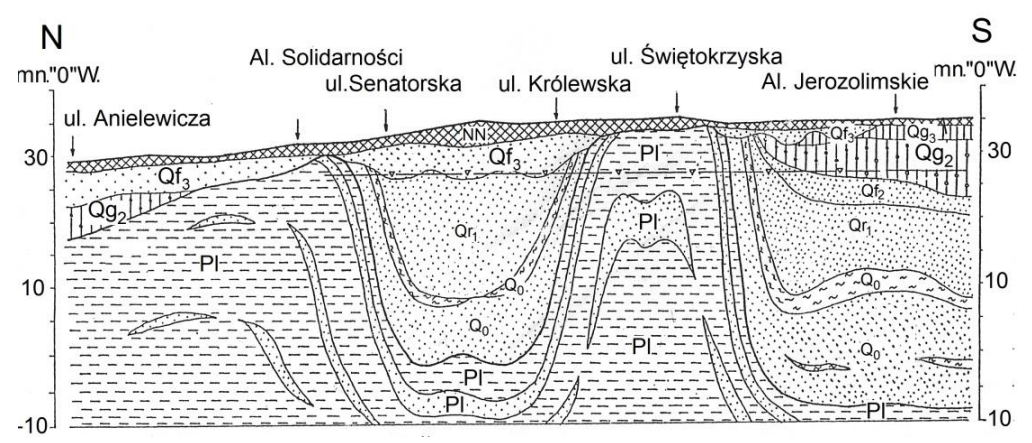

Fig. 1. Geological cross section along the main street in city centre in Warsaw (Marszałkowska street) [2].

\section{GEOTECHNICAL CONDITIONS}

The construction was executed in the difficult subsoil conditions with complicated geological past. The analysed area is situated on the glacial plateau, covered anthropogenic embankments. There are three geological layers in the substrate of construction: fluvioglacial (medium to coarse) sands of the Warta glaciation (Qf3) with a thickness of 4.6 metre, moraine sandy clay of the Odra glaciation (Qg2) with a thickness of $4.5 \mathrm{~m}$, and below layer of Mio-pliocene clays. The ground water level is located 7.5 meters below ground level in fluvioglacial sands.

Geotechnical parameters of geological layers and structural elements, are mostly taken from the geotechnical project of the metro station. The soil stiffness depends significantly on the stress level. In order to account for the increase of the stiffness with depth in the clay layer (beginning with the level of $-14 \mathrm{~m}$ ), in the numerical computations using the Coulomb-Mohr model, a procedure E-increment was used. This means the linear increase of the Young's modulus per unit of depth was assumed for the clay layer. The authors assumed a reference value of elastic modulus $\mathrm{E}_{\mathrm{ref}}=180000$ $\mathrm{kN} / \mathrm{m}^{2}$ at the level $\mathrm{y}_{\mathrm{ref}}=-14 \mathrm{~m}$ where the clayey soil starts (see Fig. 5), and the modulus increment per unit of depth $\mathrm{E}_{\mathrm{inc}}=7000 \mathrm{kN} / \mathrm{m}^{2}$. In the analysis the authors used material constants determined from the laboratory tests carried out for the Mio-pliocene clays. The value of elastic modulus was obtained from Bender Element Tests in the range of small deformations [11]. It is several times higher than those listed in the Polish Standard [17]. The parameters $\lambda$ and $\kappa$ for the Modified Cam-Clay and Soft Soil models are also adopted on the basis of authors' own oedometric tests. 
Table 1. Geotechnical parameters of soil layers: Coulomb-Mohr model.

\begin{tabular}{ccccccc}
\hline Soil layer & $\begin{array}{c}\text { Unit } \\
\text { weight } \\
\gamma\left[\mathrm{kN} / \mathrm{m}^{3}\right]\end{array}$ & $\begin{array}{c}\text { Young's } \\
\text { modulus } \\
E\left[\mathrm{kN} / \mathrm{m}^{3}\right]\end{array}$ & $\begin{array}{c}\text { Poisson's } \\
\text { ratio } \\
v[-]\end{array}$ & $\begin{array}{c}\text { Cohesion } \\
c^{\prime}[\mathrm{kPa}]\end{array}$ & $\begin{array}{c}\text { Friction } \\
\text { angle } \\
\phi^{\prime}[\mathrm{deg}]\end{array}$ & $\begin{array}{c}\text { Dilatancy } \\
\text { angle }\end{array}$ \\
\hline VIII Qf3c $(\mathrm{MSa} / \mathrm{CSa})$ & 19 & 50000 & 0.25 & 1 & 34 & 4 \\
\hline III Qg2c (saCl) & 21 & 50000 & 0.29 & 1 & 31 & 1 \\
\hline $\begin{array}{l}\text { I Plc (Clay) } \\
\text { IPld (Clay) }\end{array}$ & 23 & $\begin{array}{c}E_{\text {ref }}=180000 \\
E_{\text {inc }}=7000 \\
y_{\text {ref }}=-14 m\end{array}$ & 0.37 & 15 & 18 & 0 \\
\hline
\end{tabular}

Table 2: Geotechnical parameters of mio-pliocen clay layer: Porous Elastic and Modified Cam-Clay models.

\begin{tabular}{ccccc}
\hline $\begin{array}{c}\text { Swelling } \\
\text { index } \\
\kappa[-]\end{array}$ & $\begin{array}{c}\text { Compression } \\
\text { index } \\
\lambda[-]\end{array}$ & $\begin{array}{c}\text { Slope of the CSL } \\
\text { in q-p'space } \\
M[-]\end{array}$ & $\begin{array}{c}\text { Initial } \\
\text { void ratio } \\
e_{0}[-]\end{array}$ & $\begin{array}{c}\text { Intercept of the NCL } \\
\text { with void ratio axis } \\
e_{1}[-]\end{array}$ \\
\hline 0.017 & 0.034 & 0.71 & 0.57 & 0.82 \\
\hline
\end{tabular}

Table 3: Geotechnical parameters of mio-pliocen clay layer: Soft Soil model.

\begin{tabular}{ccccc}
\hline $\begin{array}{c}\text { Modified } \\
\text { swelling index } \\
\kappa^{*}[-]\end{array}$ & $\begin{array}{c}\text { Modified } \\
\text { compression index } \\
\lambda^{*}[-]\end{array}$ & Parameter & $\begin{array}{c}\text { Initial } \\
\text { void ratio } \\
e_{0}[-]\end{array}$ & $\begin{array}{c}\text { Poisson's } \\
\text { ratio } \\
v[-]\end{array}$ \\
\hline 0.0098 & 0.024 & $K_{0}^{N C}[-]$ & 0.57 & 0.2 \\
\hline
\end{tabular}

Geotechnical parameters for each soil layer are shown in Tables 1, 2 and 3. In case of Modified CamClay model, additional parameters $\beta=1.0$ and $K=1.0$ were used, where $\beta$ and $K$ implicate the yield surface shape in meridional and deviatoric planes respectively [15].

\section{Constitutive models of SoIl in PlaXis ANd AbaQuS}

Nowadays engineers can use various FEM software in order to solve real design problems. Some of those codes are dedicated to specific applications in geotechnics, e.g. Plaxis, Geo 5, zSoil. Other codes like Abaqus, Ansys, LS-Dyna are of general use. In this paper we apply two selected programs: Abaqus and Plaxis.

Abaqus is a commercial FEM code which has not been designed exclusively for solving soil mechanics problems like, for example, Plaxis. It is a general purpose FEM program which allows for solving a wide variety of physics phenomena and can be effectively used by both engineers and scientists. There are several approaches to soil modelling proposed in Abaqus system. It is not so 
many as in Plaxis, however Abaqus models offer a wide range of possible modifications, often giving the possibility to obtain similar ideas, like those presented as separate models in Plaxis. In Plaxis separate model include elastic and plastic behaviour. In Abaqus elastic and plastic properties of material are defined always separately.

In this section we describe constitutive models used both in Plaxis and Abaqus during computer simulation of the diaphragm wall, pointing out possible differences between these two applications. It should be emphasized that in some cases of constitutive description we put our own interpretation to the ideas and models presented in Abaqus and Plaxis manuals. Perfectly saturated conditions with no seepage were assumed in this description, so every quantity should be treated as effective.

\subsection{Porous elasticity}

Except for the common linear elastic material behaviour, soil mechanics offers a nonlinear, isotropic elasticity model where pressure stress is exponentially dependent on volumetric strain according to relation [5]:

$$
p=p_{0} \exp \left[\frac{1+e_{0}}{\kappa}\left(1-\exp \varepsilon_{v o l}^{e l}\right)\right]
$$

or

$$
\frac{\kappa}{\left(1+e_{0}\right)} \ln \left(\frac{p_{0}}{p}\right)=J^{e l}-1
$$

where: $p_{0}=-\frac{1}{3} \operatorname{tr}\left(\sigma_{0}\right), p=-\frac{1}{3} \operatorname{tr} \sigma-$ the initial and current value of the effective equivalent pressure stress, respectively, $e_{0}-$ the initial void ratio, $\varepsilon_{v o l}^{e l}-\operatorname{logarithmic}$ volumetric strain measure, $\kappa-$ swelling index (unloading-reloading line slope or logarithmic bulk modulus in [5]).

$J^{e l}$ denotes the elastic part of the volume ratio between the current and reference configurations [5], that is

$$
J^{e l}=\frac{V}{V_{0}}
$$

Let us note that

$$
\frac{\Delta V}{V}=\frac{\Delta e}{1+e} \quad, \quad \frac{\Delta V}{V_{0}}=\frac{\Delta e}{1+e_{0}}
$$

Thus, we can derive

$$
J^{e l}=\frac{1+e}{1+e_{0}}
$$

The nominal volumetric strain $\varepsilon_{n o m}=J^{e l}-1$ is connected with the logarithmic volumetric strain measure

$$
\varepsilon_{\text {log }}=\varepsilon_{\text {vol }}^{e l}=\ln \left(1+\varepsilon_{n o m}\right)=\ln J^{e l}
$$


In Abaqus, the instantaneous bulk modulus is defined as (see Eq. (4.5))

$$
K_{t}==\frac{1+e_{0}}{\kappa} p J^{e l}=\frac{1+e}{\kappa} p
$$

Then, the instantaneous shear modulus $G_{t}$ can be calculated from (4.7) and Poisson's ratio $v$

$$
G_{t}=\frac{3(1-2 v) K_{t}}{2(1+v)}=\frac{3(1-2 v)\left(1+e_{0}\right)}{2(1+v) \kappa} p J^{e l}
$$

It is worth pointing out that the relation (4.2) can be obtained considering an isotropic or oedometric compression test where we can assume that the change in void ratio equals

$$
\Delta e=\kappa\left(\ln p_{0}-\ln p\right)=\kappa \ln \left(\frac{p_{0}}{p}\right)
$$

Substituting equations (4.4) we obtain

$$
\frac{\Delta V}{V_{0}}=\frac{V-V_{0}}{V_{0}}=J^{e l}-1=\frac{\kappa}{\left(1+e_{0}\right)} \ln \left(\frac{p_{0}}{p}\right)
$$

In Plaxis, a similar idea is used in relation to the Soft Soil model [16] (see Eq. (4.7)). The unloadingreloading bulk modulus is formulated as

$$
K_{u r}=\frac{E_{u r}}{3\left(1-2 v_{u r}\right)}=\frac{p}{\kappa^{*}}=\frac{1+e}{\kappa} p
$$

where: $E_{u r}, v_{u r}$ - unloading-reloading elastic properties.

\subsection{Coulomb-Mohr model in Plaxis ANd AbaQuS}

In Plaxis Coulomb-Mohr (CM) model is understood as an elastic-perfectly plastic material behaviour with Coulomb-Mohr yield condition. In Abaqus Coulomb-Mohr yield condition is an independent material model which can be expanded by adding cohesion hardening. In Abaqus linear elastic behaviour has to be defined with Coulomb-Mohr yield condition.

In case of three-dimentional space, using principal stresses, CM criterion can be expressed by six yield surfaces [16]. It can also be formulated using three stress invariants [5]:

$$
F=R_{m c} q-p \tan \phi-c=0
$$

where

$$
R_{m c}(\theta, \phi)=\frac{1}{\sqrt{3} \cos \phi} \sin \left(\theta+\frac{\pi}{3}\right)+\frac{1}{3} \cos \left(\theta+\frac{\pi}{3}\right) \tan \phi
$$

and polar angle $\theta$ (Lode's angle) is defined as

$$
\cos (3 \theta)=\left(\frac{r}{q}\right)^{3}=\frac{3 \sqrt{3}}{2} \cdot \frac{J_{3}}{J_{2}^{3 / 2}}
$$

The three stress invariants used in Eq. (4.12) and (4.14) are as follows:

$$
p=-I_{1}=-\frac{1}{3} \operatorname{tr}(\boldsymbol{\sigma})
$$




$$
\begin{gathered}
q=\sqrt{\frac{3}{2} \boldsymbol{s} \cdot \boldsymbol{s}}=\sqrt{3 J_{2}} \\
r=\sqrt[3]{\frac{9}{2}(\boldsymbol{s s}) \cdot \boldsymbol{s}}=3 \sqrt[3]{\frac{1}{2} J_{3}} .
\end{gathered}
$$

where the deviator stress tensor $\boldsymbol{s}=\boldsymbol{\sigma}+p \boldsymbol{I}$ and commonly used stress invariants are $J_{2}=\frac{1}{2} \boldsymbol{s} \cdot \boldsymbol{s}$, $J_{3}=\frac{1}{3} \boldsymbol{s} \boldsymbol{s} \cdot \boldsymbol{s}$ and "." denotes scalar product. Derivation of the Coulomb-Mohr failure condition form, similar to Eq. (4.12), can be found, for example, in [13].

Plaxis, as well as Abaqus, include a possibility to add "tension cut-off" to reduce tension strength of a soil material, which arises for $c>0$ using standard Mohr-Coulomb criterion.

In Plaxis, plastic potential function has no smooth corner transition as it resembles Coulomb-Mohr surface:

$$
G_{p l x}=R_{m c}(\theta, \psi) q-p \tan \psi
$$

where: $\psi$ - dilatancy angle.

As a sharp transition from one yield surface to another is used, Plaxis treats corners according to the Koiter's proposal [16].

In general, the plastic flow rule is not associated in CM model in Abaqus either. However, a smooth approximation of the classic CM surface is assumed. The flow potential, $G$, is chosen as a hyperbolic function in the meridional stress plane and the smooth elliptic function proposed by Menétrey and Willam in the deviatoric stress plane $[5,12]$

$$
G_{m w}=\sqrt{\left(\left.\epsilon c\right|_{0} \tan \psi\right)^{2}+\left(R_{m w} q\right)^{2}}-p \tan \psi
$$

where

$$
R_{m w}(\theta, d)=\frac{3\left(1-d^{2}\right) \cos ^{2} \theta+(2 d-1)^{2}}{2\left(1-d^{2}\right) \cos \theta+(2 d-1) \sqrt{4\left(1-d^{2}\right) \cos ^{2} \theta+5 d^{2}-4 d}} R_{m c}\left(\frac{\pi}{3}, \psi\right)
$$

where: $\left.c\right|_{0}$ - initial cohesion yield stress $\left(\left.c\right|_{0}=\left.c\right|_{\bar{\varepsilon}} p l\right), \epsilon-$ parameter called meridional eccentricity, which defined the rate at which the hyperbolic function approaches the asymptote in the meridional stress plane, $d$ - parameter called deviatoric eccentricity which describes the roundedness of the deviatoric section (Fig. 2).

CM model can be used only with linear elasticity. As stiffness in real soils significantly depends on the depth it is important to add variation of Young's modulus with the vertical coordinate. Plaxis has the capability to add a linear variation of Young's modulus according to the following relation:

$$
E(y)=E_{\text {ref }}+\left(y_{\text {ref }}-z\right) E_{\text {inc }}, y<y_{\text {inc }}
$$

where: $y$-vertical coordinate, $E_{\text {ref }}$ - a reference value of the modulus at a level $y_{\text {ref }}, E_{\text {inc }}-$ increase of the modulus per unit of depth $[14,16]$. A similar dependency can be applied to cohesion. 
The same can be done in Abaqus by applying a user subroutine USDFLD. This approach gives the possibility to implement no only a linear change with depth, but any function, which best describes field tests' results. The procedure in Abaqus can be applied to any material parameter.

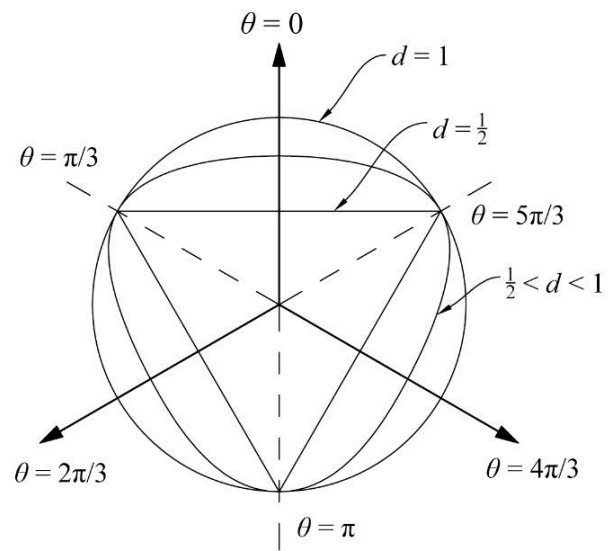

Fig. 2. Influence of the deviatoric eccentricity $d$ on the deviatoric section's shape; $d=1 / 2-$ Rankine; $d=0$ - Huber-Mises; $1 / 2<d<1-$ Monétrey-Willam.

\subsection{Modified Cam-Clay model in AbaQuS}

The Abaqus Modified Cam-Clay model's yield surface can be defined as follows [5, 8]:

$$
\frac{1}{\beta^{2}}\left(\frac{p}{a}-1\right)^{2}+\left(\frac{t}{M a}\right)^{2}-1=0
$$

where

$$
t=\frac{1}{2} q\left[1+\frac{1}{K}-\left(1-\frac{1}{K}\right)\left(\frac{r}{q}\right)^{3}\right]
$$

where: $M$ - parameter defining the slope of the critical state line in $p-t$ plane (the ratio of $t$ to $p$ at the critical state), $\beta \in(0 ; 1]$ - constant that defines the shape of the Cam yield ellipse in the meridional plane (Fig. 3), $K$ - parameter that controls shape of a projection of the Modified CamClay model in the deviatoric plane, $a$-hardening parameter that controls the size of the yield surface (Fig. 3).

Let us note that for the default value of $K=1$ and $t=q$, the deviatoric cross-sections is a circle the yield surface is independent of the third stress invariant. To ensure convexity of the yield surface, the values of $K \in[0.778 ; 1.0]$ should be used. Variable $a$ defines the point on the p-axis at which the evolving elliptic arcs of the yield surface intersect the critical-state line [8]. 
In Abaqus the hardening law can be of exponential, or piecewise linear form. The exponential form can only be used in conjunction with Abaqus Porous Elastic model described in section 4.1. The size evolution of the yield surface is determined according to the following equation:

$$
a=a_{0} \exp \left[\left(1+e_{0}\right) \frac{1-J^{p l}}{\lambda-\kappa J^{p l}}\right]
$$

where: $J^{p l}$ - plastic part of the volume change e.g. $J=J^{p l}+J^{e l}$ (see Eq. (4.5) where $J^{p l}=0$ is assumed), $e_{0}$ - initial void ratio, $\lambda$ - compression index.

In Plaxis Soft Soil model a similar hardening law is used (see Eq. (4.26)). Here, the parameter $a_{0}$ is related to the initial preconsolidation stress.

The initial size of the yield surface is defined for the Modified Cam-Clay model by specifying the hardening parameter, $a_{0}$, directly as a tabular function of initial parameters or by defining it analytically [5].

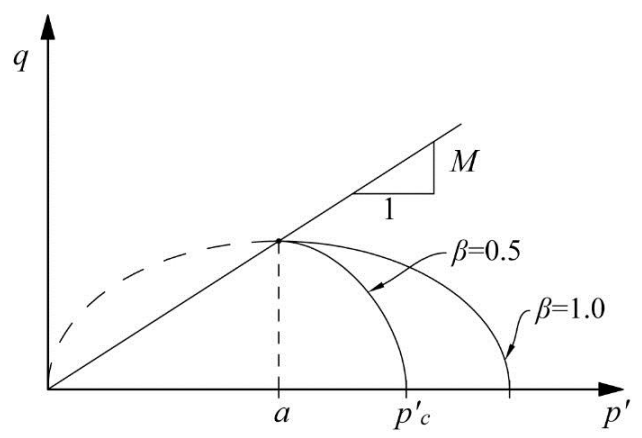

Fig. 3. Abaqus Modified Cam-Clay yield surface in the meridional stress plane for $K=1$ $\left(p_{c}\right.$ - pre-consolidation pressure).

\subsection{Soft SoIL MOdel IN Plaxis}

For description of constitutive properties of clays Plaxis offers Soft Soil model, which is also a modification of original Cam-Clay idea. Soft Soil model is preferred in Plaxis, as it provides safer predictions. The Soft Soil model's yield function for the triaxial compression stress state is as follows [16]:

$$
f=\frac{q^{2}}{M^{2}\left(p^{\prime}+c \cot \varphi\right)}+p^{\prime}-p_{c}
$$

where: $p_{c}$-pre-consolidation stress, $c$-cohesion, $\varphi$-internal friction angle, $M$-parameter determining the height of the yield ellipse i.e. the critical state line (Fig. 4). 
The pre-consolidation stress is a function of volumetric plastic strain $\left(\varepsilon_{v}^{p}\right)$, according to the following hardening relation

$$
p_{c}=p_{c}^{0} \exp \left(\frac{-\varepsilon_{v}^{p}}{\lambda^{*}-\kappa^{*}}\right)
$$

where: $\lambda^{*}, \kappa^{*}$ - modified compression index and modified swelling index respectively, $p_{c}^{0}-$ the initial value of pre-consolidation stress. Modified compression and swelling indexes are related to the parameters used in the Cam-Clay model such that

$$
\lambda^{*}=\frac{\lambda}{1+e} \quad \kappa^{*}=\frac{\kappa}{1+e}
$$

The height of the yield ellipse determines the ratio of horizontal to vertical stresses. Thus, the parameter $M$ is strongly connected with the coefficient of lateral earth pressure. In case of the Soft Soil model, $M$ is automatically determined based on the coefficient of lateral earth pressure assuming normally consolidated condition, $K_{0}^{n c}$. The exact relation between $M$ and $K_{0}^{n c}$ is given as $[3,16]$

$$
M=3 \sqrt{\frac{\left(1-K_{0}^{n c}\right)^{2}}{\left(1+2 K_{0}^{n c}\right)^{2}}+\frac{\left(1-K_{0}^{n c}\right)\left(1-2 v_{u r}\right)\left(\frac{\lambda^{*}}{\kappa^{*}}-1\right)}{\left(1+2 K_{0}^{n c}\right)\left(1-2 v_{u r}\right) \frac{\lambda^{*}}{\kappa^{*}}-\left(1-K_{0}^{n c}\right)\left(1+v_{u r}\right)}}
$$

Whereas in the Cam-Clay model the critical state line, which 'cuts' the yield ellipse, is determined by $M$, in the Soft Soil model, an additional Coulomb-Mohr surface is added to limit the yield surface and to separate failure from the M-line (Fig. 4). The slope of the C-M failure line is smaller than the slope of the M-line. Thus, in general stress states, the Soft Soil model yield surface is defined by six yield surfaces forming a Coulomb-Mohr surface with a cap and hardening behaviour [19].

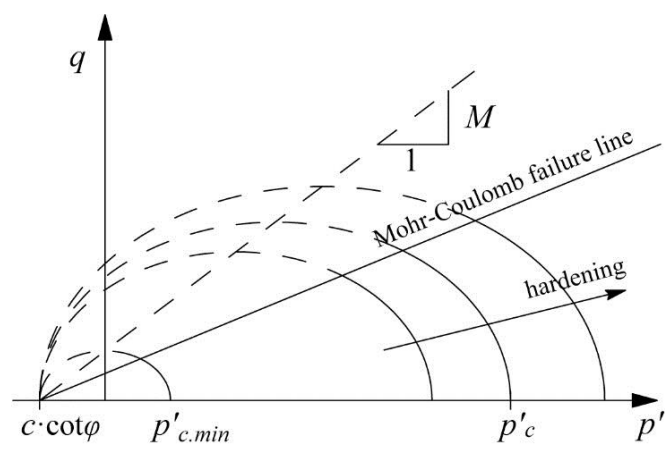

Fig. 4. Yield surface of the Soft Soil model in the meridional plane. 


\section{Preparation of FEM Model}

The analysed case study is a three level underground structure, which is located in the central section of the second metro line in Warsaw. The excavation was carried out in stages. The sides of the excavation are supported by almost $30 \mathrm{~m}$ long diaphragm walls, with a thickness of 1.2 meters. This construction is founded on a $1.2 \mathrm{~m}$ thick slab at the depth of $25.5 \mathrm{~m}$ below the ground level. Diaphragm wall is submerged in the Pliocene clays from the depth of $14.0 \mathrm{~m}$ below ground level preventing the excavation against the water flow. During the construction, continuous monitoring of diaphragm wall displacements has been carried out using automatic inclinometers. The cross-section including geological layers and the stages of construction are shown in Fig. 5. The stages of construction, related also in FE calculation steps were as follows: (i) excavation to the depth of 4.90 $\mathrm{m}$, (ii) casting of " 0 " slab, with $1.20 \mathrm{~m}$ thick, (iii) excavation to the depth of $9.80 \mathrm{~m}$, (iv) casting of "-1" slab, with $0.60 \mathrm{~m}$ thick, (v) excavation to the depth of $17.20 \mathrm{~m}$, (vi) casting of "-2" slab, with $0.50 \mathrm{~m}$ thick, (vii) final excavation to the depth of $25.20 \mathrm{~m}$, (viii) casting of foundation slab, $1.20 \mathrm{~m}$ thick.

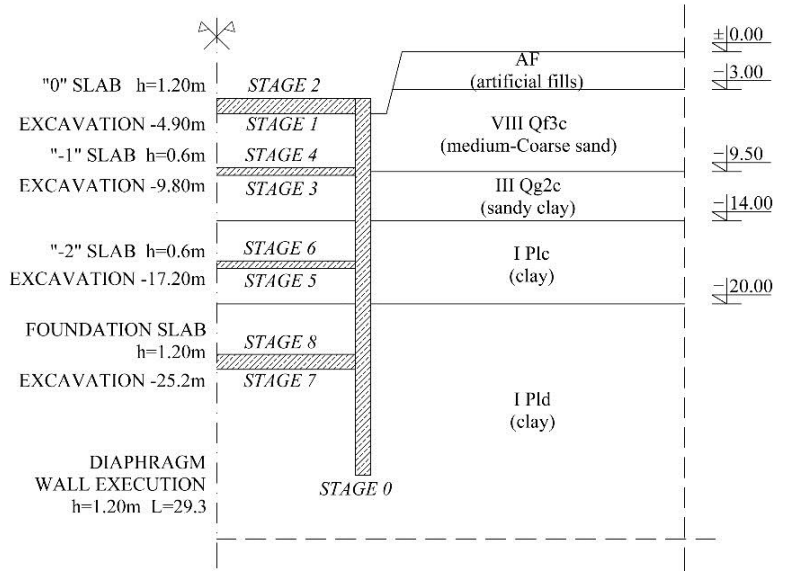

Fig. 5. The cross-section: structure's geometry and construction stages.

\subsection{Plaxis}

The FEM model was built using 4003 15-node elements giving 32842 nodes and 48036 stress points. Contact elements were applied for modelling the interaction between the soil and the structure. The diaphragm wall and the foundation slab were modelled with finite elements and were described with 
a linear elastic material characteristics $E_{\text {ref }}=33 G P a, v=0.2$. Diaphragm walls were braced by horizontal struts at an interval of $1.0 \mathrm{~m}$. The struts were modelled as spring elements for which the normal stiffness was a required input parameter.

Along the excavation the surface load was taken into account, which simulated the load from the residual soil above the first level of the excavation. From a depth of $7.5 \mathrm{~m}$ below ground level to a depth of $14.0 \mathrm{~m}$ additional load on the diaphragm wall was taken into account, simulating an increase of stresses from the underground water table.

\subsection{ABaquS}

The structure was modelled to be 45 meters high and 50 meters wide. Symmetry boundary conditions (horizontal displacement $u_{x}=0$ ) were applied to the left vertical side (symmetry line) of the model and to the left ends of struts. At the right vertical side also $\mathrm{u}_{\mathrm{x}}=0$ was assumed and $\mathrm{u}_{\mathrm{y}}=0$ at the bottom side. Struts were pinned to the diaphragm wall so that rotation was allowed in these points (joints). The soil space as well as the concrete wall and the bottom concrete slab were divided into 4821 8 -node bi-quadratic plane strain quadrilateral elements with reduced integration. The struts were modelled with 97 3-node quadratic beam elements. Such mesh gave 15313 nodes in total for the whole model.

Elastic properties of reinforced concrete were the same as in the Plaxis model. This material was also applied to the beam elements modelling the struts. The load resulting from residual soil above the level of the excavation was applied as a surface load in the vertical direction. A thin elastic layer was modelled below the applied surface load to avoid convergence problems and to improve force distribution. Gravity acceleration $\mathrm{g}=10 \mathrm{~m} / \mathrm{s}^{2}$ was applied to the whole model except for struts.

In the approach where the Coulomb-Mohr model was chosen for the clay layer, a user subroutine USDFLD was used to implement linear change of the elastic Young's modulus with depth.

To model the interface between the diaphragm wall and soil, surface-to-surface contact definition with penalty constraint enforcement method was chosen. In addition, contact initiation procedure was applied to remove over-closures or clearances. Moreover, no separation after achieving contact was allowed. In this case Abaqus uses the Coulomb friction law. Thus, friction coefficient was needed as an input parameter. Assuming that clayey layer significantly affects diaphragm wall deflection coefficient of friction was chosen taking into account clay layer's internal effective friction angle. Assuming that the interface friction angle $\delta$ can't be higher than the soil internal friction angle [6]:

$$
\mu=\tan \delta=\tan \phi \approx 0.3
$$


In order to avoid convergence problems related to instabilities of material nature caused by nonlinear constitutive theory, Abaqus automatic stabilization procedure was used during calculations. This procedure adds volume-proportional damping to the model to account for localized instabilities. Damping factors can be constant or can change over the duration of an analysis step. In the constant damping factor approach, viscous forces of the form [5]:

$$
F_{v}=c \boldsymbol{M}^{*} \boldsymbol{v}
$$

are added to the global equilibrium equations:

$$
P-I-F_{v}=0
$$

where: $\boldsymbol{M}^{*}$ - artificial mass matrix calculated with unity density, $c$ - damping factor, $v=\Delta u / \Delta t-$ vector of nodal velocities, $P$ - externally applied forces, $I$ - internally generated forces [5].

Because it is difficult to estimate proper damping factor value for the whole analysis step, the adaptive automatic stabilization scheme, in which the damping factor can vary in the course of a step, was chosen in this paper calculations. In this case the damping factor is controlled by Abaqus, considering convergence history and the ratio of the energy dissipated by viscous damping to the total strain energy [5]. This ratio was an additional input parameter.

In order to check if the damping factor introduced to the model did not affect global solution, it was necessary to ensure that viscous forces were relatively small in comparison to overall forces. We compared the viscous damping energy with the total strain energy. Damping energy appeared to be 3 levels of magnitude lower than the total strain energy proving that the stabilization did not affect results.

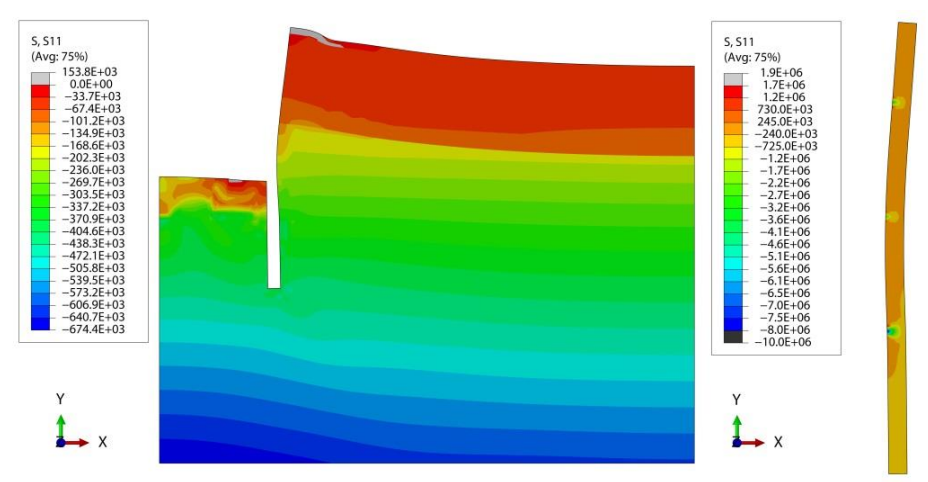

Fig. 6. Abaqus results. Modified Cam-Clay model used for the clay layer. Contour plot of horizontal effective stress component $\sigma_{11}$. Deformed structure. Displacement scaling factor: 50. 


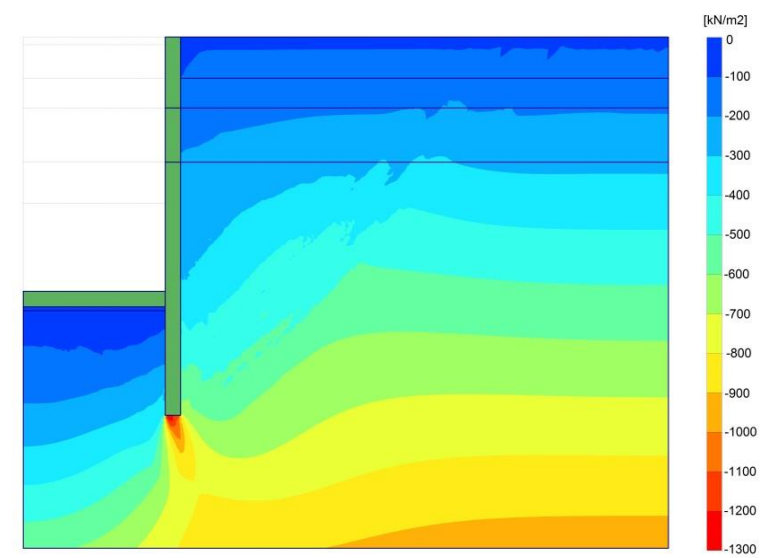

Fig. 7. Plaxis results. Coulomb-Mohr model used for the clay layer. Contour plot of vertical effective stress component $\sigma_{22}$. Undeformed structure.

\section{Conclusions}

Horizontal and vertical displacements as well as effective stresses resulting from computer calculations were compared to the results of in-situ displacements' measurements and presented in Table 4. The values of the maximum horizontal displacements are taken from the diaphragm wall while the vertical displacements are taken from the bottom concrete slab.

Analysing the results of horizontal and vertical displacements one can see strong differences between the obtained values using both FEM codes and various constitutive models of clay. The best convergence with respect to the measured value (horizontal displacement $15.0 \mathrm{~mm}$ in Table 4) was obtained applying the Abaqus Coulomb-Mohr model (16.8 mm).

Selected graphical visualizations of stresses are shown in Fig. 6 and Fig. 7. The values of the maximum horizontal and vertical stresses presented in Table 4, do not differ so much as it was in case of displacements. This is quite optimistic conclusion. Nevertheless, the divergences in displacements should lead us to the conclusion that the computer calculations in geotechnics must be always viewed with a great caution as they strongly depend on the constitutive model and the FE code we used. Applying a model having the same name in various FEM codes (e.g. Coulomb-Mohr model) does not necessarily lead to similar results. The reasons of such a situation are not only the differences in constitutive description but also algorithms of numerical integration applied, types of finite elements, location of Gauss points at elements and many other factors. 
Table 4: Comparison of FEM program results.

\begin{tabular}{ccccccc}
\hline & Plaxis & Abaqus & Plaxis & Abaqus & $\begin{array}{c}\text { Measured } \\
\text { value }\end{array}$ \\
\hline $\begin{array}{c}\text { Type of model } \\
\text { for clay layer }\end{array}$ & Soft Soil & $\begin{array}{c}\text { Modified } \\
\text { Cam-Clay }\end{array}$ & Coulomb-Mohr & \\
\hline $\begin{array}{c}\text { Horizontal } \\
\text { displacement }\end{array}$ & $\begin{array}{c}\text { Extreme } \\
U_{z}[\mathrm{~mm}]\end{array}$ & 60.1 & 24.6 & 33.5 & 16.8 & 15.0 \\
\hline $\begin{array}{c}\text { Vertical } \\
\text { displacement }\end{array}$ & $\begin{array}{c}\text { Extreme } \\
U_{y}[\mathrm{~mm}]\end{array}$ & 147.9 & 47.0 & 39.8 & 50.2 & \\
\hline $\begin{array}{c}\text { Horizontal } \\
\text { effective stress }\end{array}$ & {$\left[\mathrm{kN} / \mathrm{m}^{2}\right]$} & -615.3 & -674.4 & -690.6 & -667.7 & \\
\hline $\begin{array}{c}\text { Vertical } \\
\text { effective stress }\end{array}$ & {$\left[\mathrm{kN} / \mathrm{m}^{2}\right]$} & -1050.0 & -1072.0 & -1250.0 & -1084.0 & \\
\hline
\end{tabular}

\section{REFERENCES}

1. M. Barański, "Selected properties of clays based on field tests. Pliocene clays in Warsaw.", ITB seminar Iły Pliocenskie Warszawy, pp 15-30, 2004.

2. Borowczyk M.: The behaviour of Pliocene clays in foundation excavations. ITB seminar Iły plioceńskie Warszawy, pp. 31-47, 2004.

3. R. B. J. Brinkgreve, "Geomaterial Models and Numerical Analysis of Softening", PhD thesis, Delft University of Technology, 1994.

4. M. Cudny, (2013). "Some aspects of the constitutive modelling of natural fine grained soils", Ed. by E. Dembicki, IMOGEOR, 2013.

5. Dassault Systèmes (2012). Abaqus Analysis User's Manual, Ver. 6.11, Dassault Systèmes, 2012.

6. Y. Diao, G. Zheng (2008). "Numerical analysis of effect of friction between diaphragm wall and soil on braced excavation", Journal of Central South University of Technology 15.2, pp 81-86, 2008.

7. J. M. Dłużewski, "Numerical Modelling of soil-structure interactions in consolidation problems", Vol. 123. Prace Naukowe: Budownictwo, Wydawnictwa Politechniki Warszawskiej, 1993.

8. S. Helwany, "Applied Soil Mechanics with Abaqus Applications", John Wiley \& Sons, Inc., 2007.

9. P. Y. Hicher, "Constitutive modelling of soils and rocks", Ed. by J. F. Shao., ISTE Ltd, John Wiley and Sons, 2008.

10. Z. J. Kozyra, A. Zbiciak, K. Józefiak, "FEM analysis of an influence of subway's vibration on a building”, in Polish, TTS Technika Transportu Szynowego 18.9, 2012.

11. R. Kuszyk, M. Superczyńska, A. Lejzerowicz, "The research methods of elastic parameters of Pliocene clays for the second subway line in Warsaw", in Polish, Przegląd Komunikacyjny 9, pp 59-63, 2012.

12. Ph. Menétrey, J. K. Willam, "Triaxial Failure Criterion for Concrete and Its Generalization". ACI Structural, pp. 311-318, 1995.

13. F. Oka, S. Kimoto, "Computational Modelling of Multiphase Geomaterials", CRC Press, Taylor \& Francis Group, LLC, 2013.

14. N. S. Ottosen, M. Ristinmaa, "The Mechanics of Constitutive Modelling”, Elsevier, 2005.

15. S. Pietruszczak, "Fundamentals of Plasticity in Geomechanics" CRC Press, 2010.

16. Plaxis, Plaxis Material Models Manual 2014. Plaxis, 2014.

17. PN-81/B-03020: Building soils. Foundation bases. Static calculation and design, Polish Standard, Polish Committee for Standardization, 1981.

18. Z. Sarnacka, "Stratigraphy of Quaternary sediments of Warsaw and its vicinity", Polish Geological Institute, 1992.

19. H. S. Yu, "Plasticity and Geotechnics. Advances in Mechanics and Mathematics", Vol. 13, Springer, 2006.

20. A. Zbiciak, M. Maślakowski, and R. Michalczyk, "Strength analysis of a certain expressway embankment", Polish-Ukrainian Transactions "Theoretical Foundations of Civil Engineering". Vol. 20, pp 137-148, 2012.

21. A. Zbiciak, R. Michalczyk, K. Józefiak, M. Maślakowski, "Determination of cohesive soils mechanical properties using cone penetrometer: laboratory testing and numerical simulations", in Polish, Logistyka 3, 2014. 


\section{LIST OF FIGURES AND TABLES:}

Fig. 1. Geological cross section along the main street in city centre in Warsaw (Marszałkowska street).

Rys. 1. Przekrój geologiczny wzdłuż głównej ulicy w centrum Warszawy (ul. Marszałkowska).

Fig. 2. Influence of the deviatoric eccentricity $d$ on the deviatoric section's shape.

Rys. 2. Wpływ parametru $d$ na kształt powierzchni w przekroju dewiatorowym.

Fig. 3. Abaqus Modified Cam-Clay yield surface in the meridional stress plane for $K=1$.

Rys. 3. Powierzchnia plastyczności modelu Modified Cam- Clay w przekroju południkowym przy $K=1$.

Fig. 4. Yield surface of the Soft Soil model in the meridional plane.

Rys. 4. Powierzchnia plastyczności modelu Soft Soil w przekroju południkowym.

Fig. 5. The cross-section: structure's geometry and construction stages.

Rys. 5. Przekrój: geometria konstrukcji oraz fazy budowy.

Fig. 6. Abaqus results. Modified Cam-Clay model used for the clay layer. Contour plot of horizontal effective stress component $\sigma_{11}$. Deformed structure. Displacement scaling factor: 50 .

Rys. 6. Wyniki z programu Abaqus. Do modelowania iłu wykorzystano Model Modified Cam-Clay. Wykres warstwicowy poziomej składowej naprężenia efektywnego $\sigma_{11}$. Konstrukcja odkształcona. Współczynnik skalowania przemieszczeń: 50 .

Fig. 7. Plaxis results. Coulomb-Mohr model used for the clay layer. Contour plot of vertical effective stress component $\sigma_{22}$. Undeformed structure.

Rys. 7. Wyniki z programu Plaxis. Do modelowania iłu wykorzystano Model Coulomb-Mohr. Wykres warstwicowy pionowej składowej naprężenia efektywnego $\sigma_{22}$. Konstrukcja nieodkształcona.

Tab. 1. Geotechnical parameters of soil layers: Coulomb-Mohr model.

Tab. 1. Parametry geotechniczne warstw podłoża gruntowego: model Coulomb-Mohr.

Tab. 2. Geotechnical parameters of mio-pliocen clay layer: Porous Elastic and Modified Cam-Clay models.

Tab. 2. Parametry geotechniczne iłu mio-plioceńskiego: modele Porous Elastic, Modified C-C.

Tab. 3. Geotechnical parameters of mio-pliocen clay layer: Soft Soil model.

Tab. 3. Parametry geotechniczne iłu mio-plioceńskiego: model Soft Soil.

Tab. 4. Comparison of FEM program results.

Tab. 4. Porównanie wyników z programów MES. 


\section{ANALIZA NUMERYCZNA ŚCIANY SZCZELINOWEJ WYKONANEJ W ILACH FORMACJI POZNAŃSKIEJ Z WYKORZYSTANIEM WYBRANYCH PROGRAMÓW MES}

Slowa kluczowe: iły formacji poznańskiej, modelowanie konstytutywne, MES, geotechnika obliczeniowa, ściana szczelinowa

\section{STRESZCZENIE:}

Projektowanie konstrukcji podziemnych w obszarach gęstej zabudowy miejskiej, może wiązać się z wieloma trudnościami. Wykop zwykle jest realizowany w bliskim sąsiedztwie istniejących budynków i infrastruktury podziemnej, jak również istnieje ryzyko wystąpienia w podłożu skomplikowanych warunków gruntowych (np. gruntów ekspansywnych lub antropogenicznych).

Obecnie inżynierowie mogą korzystać z różnych programów MES w celu rozwiązywania rzeczywistych problemów projektowych. Niektóre są przeznaczone do specyficznych zastosowań, np. w geotechnice Plaxis, Geo 5 czy zSoil. Inne komercyjne programy MES, jak np. Abaqus, Ansys czy LS-Dyna, są bardzo rozbudowane i nadają się do rozwiązywania różnorodnych zagadnień fizyki technicznej (nie tylko z zakresu mechaniki), ale nie zawsze dysponują dodatkowymi narzędziami przydatnymi w konkretnych zastosowaniach geotechnicznych.

W artykule przedstawiono wyniki analizy przemieszczeń wybranej ściany szczelinowej przeprowadzonej z zastosowaniem dwóch uznanych programów MES: Plaxis i Abaqus. Oba zawierają zestaw modeli sprężystoplastycznych gruntów, przydatnych do modelowania zachowania się iłów, ale stosowanie tych modeli wymaga dobrej znajomości mechaniki i geotechniki.

W niniejszej pracy zwrócono uwagę na istotne różnice w konstytutywnym sformułowaniu modeli sprężysto-plastycznych w wymienionych programach. Zaprezentowano wybrane elementy teorii konstytutywnej, które nie są wyjaśnione szczegółowo w podręcznikach obu programów. W niektórych przypadkach, wykorzystano specjalne techniki modelowania MES zaimplementowane w oprogramowaniu (np. procedury użytkownika w programie Abaqus) Wyniki obliczeń komputerowych zostały porównywane ze zmierzonymi wartościami poziomych przemieszczeń ściany szczelinowej.

Wybrana do analizy konstrukcja została wykonana w iłach formacji poznańskiej, które występują w centralnej Polsce jako podłoże wysokich budynków i budowli podziemnych. W okresie sedymentacji tych iłów, tj. przez ok 9 milionów lat, osiągnęły miąższość do 150 metrów. Ich naturalna struktura i poziom zalegania zostały zmienione wskutek licznych i długotrwałych procesów geologicznych aktywnych w czwartorzędzie, tj. erozji rzecznej, zaburzeń związanych z działalnością lodowców, procesów sejsmicznych i wietrzenia. Doprowadziły one do zdeformowania stropu iłów, sfałdowań i przemieszczeń, powstania luster tektonicznych oraz - szczególnie istotnych z punktu widzenia zapewnienia szczelności obudowy wykopu - soczewek piaszczystych z wodą pod wysokim ciśnieniem.

Obszar poddany analizie to wysoczyzna polodowcowa, pokryta nasypami antropogenicznymi. W podłożu występują piaski wodnolodowcowe, glina morenowa, a poniżej - warstwy iłów mio-plioceńskich. Poziom wody gruntowej znajduje się 7,5 m poniżej poziomu terenu.

W przypadku iłów mio-plioceńskich wartości parametrów geotechnicznych, wykorzystanych w analizie, uzyskano na podstawie własnych badań laboratoryjnych. Wartość modułu sprężystości otrzymano z badań z zastosowaniem piezoelementów typu bender. Parametry $\lambda$ i $\kappa$, dla modelu Modified Cam-Clay i Soft soil, przyjęto na podstawie badań edometrycznych. W celu uwzględnienia zwiększenia sztywności wraz z głębokością, w obliczeniach numerycznych 
z wykorzystaniem modelu Coulomba-Mohra, zastosowano procedurę użytkownika USDFLD, którą zaprogramowano w języku Fortran.

Analizowana ściana szczelinowa jest częścią trzykondygnacyjnej konstrukcji podziemnej, realizowanej w centralnym odcinku drugiej linii metra w Warszawie. W artykule przedstawiono wymiary konstrukcji, etapy realizacji wykopu oraz profil geologiczny podłoża gruntowego. Podczas budowy prowadzono ciągłe monitorowanie przemieszczeń ściany szczelinowej za pomocą automatycznych inklinometrów.

Model MES w Plaxisie został zbudowany przy użyciu 4003 elementów 15 węzłowych, co przełożyło się na 32842 węzłów i 48036 punktów Gaussa. Do zamodelowania interakcji pomiędzy gruntem i konstrukcją zastosowano elementy kontaktowe. Ściana szczelinowa i płyta fundamentowa zamodelowane zostały z wykorzystaniem elementów skończonych i opisane jako materiał liniowo sprężysty. Ściany szczelinowe zostały usztywnione przez poziome rozpory w odstępie 1,0 m. Od głębokości 7,5 m poniżej poziomu gruntu do głębokości 14,0 m uwzględniono dodatkowe obciążenie na ścianę, modelując wzrost naprężeń od zwierciadła wody gruntowej. Zastosowano standardowe warunki brzegowe.

W programie Abaqus zastosowano siatką 4821 elementów 8-węzłowych w odniesieniu do przestrzeni gruntowej, ściany szczelinowej i płyty dennej oraz 97 elementów 3-węzłowych dla elementów belkowych, co dało 15313 węzłów w całym modelu. Zastosowano identyczne warunki brzegowe jak w programie Plaxis. Własności materiałowe gruntów i ściany, w obu przypadkach są takie same.

Wynikiem przeprowadzonej analizy jest porównanie wartości przemieszczeń uzyskanych na podstawie obliczeń komputerowych z wartościami pomiarów, ,in situ”. W artykule zestawiono maksymalne przemieszczenia poziome, związane z deformacją ściany szczelinowej, oraz przemieszczenia pionowe, będące rezultatem przemieszczeń płyty dennej. Wyniki obliczeń wskazują na istotne różnice pomiędzy wartościami uzyskanymi z wykorzystaniem różnych programów MES, jak i zastosowaniem różnych modeli konstytutywnych. Największą zbieżność z wartościami pomierzonymi (przemieszczenie poziome wynoszące 15,0 mm) uzyskano stosując model z warunkiem Coulomba-Mohra w programie Abaqus. Wartości maksymalnych efektywnych naprężeń poziomych i pionowych nie różnią się tak znacznie, jak wartości przemieszczeń. Niemniej jednak, wyniki analiz przedstawionych w pracy powinny prowadzić do wniosku, że obliczenia komputerowe w geotechnice zawsze muszą być traktowane z wielką ostrożnością. Ich rezultaty zależą zarówno od stosowanego oprogramowania, jaki i od modelu konstytutywnego wybranego do opisu zachowania się gruntu. Przyczynami takiej sytuacji są nie tylko różnice w opisie konstytutywnym, ale również zastosowane algorytmy całkowania numerycznego, typy elementów skończonych, lokalizacja punktów Gaussa i wiele innych czynników. 